\title{
ALLEVIATE THE ADVERSE EFFECTS OF SOME HEAVY METALS AND IMPROVE QUALITY AND STORABILITY OF TOMATO AND KIDNEY BEAN PLANTS GROWN UNDER POLLUTION CONDITIONS \\ Shabana, Abeer A. ; Huda I. Ahmed and Aml A. El-Awady \\ Vegetable Res. Dept., Hort. Res. Institute, Agric. Res. Center, Agric. Ministry, Egypt
}

\begin{abstract}
Two field and storage experiments were conducted at a private farm near the high ways and Delta company for fertilizers and chemical industries, Talka City, Dakahlia Governorate during the two successive summer seasons of 2009 and 2010 to study the effect of some heavy metals such as copper, lead and manganese by using natural antioxidants substances, i.e., humic acid, vitamin C., vitamin E. and glutathione on tomato (Lycopirsecon esculentum Mill) cv. Alissa and kidney bean (Phaseolus vulgaris L) cv. Giza 3 plants under soil pollution stress. It also aimed to improve the quality and storability of tomato and kidney bean fruits.

The most important finding could be summarized as follows:

Concerning the effect of the treatments on tomato the obtained results indicate that all natural substances of antioxidant led to significant increases in all vegetative growth parameters compared to the control.

- Application of glutathione and vitamin $C$ had a significant effect on plant height, chlorophyll a, chlorophyll b, fresh weight per plant, fruit number per plant and total fruit yield per feddan in both season of this study.

- The plant organs (roots, leaves and fruits) for the tomatoes differed in its content from the heavy metals, where the roots contained higher amount of these elements content $(\mathrm{Pb}, \mathrm{Mn}$ and $\mathrm{Cu}$ ) than the leaves, while the fruits have the suitable levels of heavy metals content, and that due to the impact of the treatments on the removal of these poisonous elements. Glutathione and vitamin $\mathrm{C}$ treatments had a highest significant effect in this respect. The control treatment led to an accumulation of the respective heavy metals content in different plant organs.

- All natural substances of antioxidants had a significant increases in quality and storability parameters of tomato fruits, expressed as a reduction in weight loss and decay percent and the preservation of the fruits contents (i.e., acidity, lycopene content, firmness, vitamin C and T.S.S) in comparison with the control of these treatments in both seasons.

While, the effect of application of glutathione and vitamin $E$ had a significant effect on most vegetative growth parameters of kidney bean in both seasons of this study.

- Glutathione, vitamin $\mathrm{C}$ and vitamin $\mathrm{E}$ treatments led to significant decrease in heavy metals content $(\mathrm{Pb}, \mathrm{Mn}$ and $\mathrm{Cu}$ ) in different plant organs of kidney bean (roots, leaves and fruits) compared to the control treatment in both seasons.

- All antioxidant treatments gave significant increases of the fruits quality and improvement storability compared to the control in the two seasons.

It could be concluded that application of glutathione, vitamin $C$ and vitamin $E$ as a natural substances of antioxidants to tomato and kidney bean plants indicated that the most effective treatments for improvement quality and storability and alleviate the adverse effects of some heavy metals under soil pollution conditions.

Keywords: tomato, bean, pollution, heavy metals, antioxidants
\end{abstract}




\section{INTRODUCTION}

Heavy metals, such as lead, manganese and copper are important elements for plants, but when increases over the critical levels become environmental pollutants and toxicants, particularly in areas with high anthropogenic pressure (Critical levels: $\mathrm{Pb} 100$ and 30; Mn 1500 and 300; $\mathrm{Cu}$ 60 and 20 ppm, in soil and plant, respectively according to Alloway, 1995). Their presence in the atmosphere, soil and water, even in traces, can cause serious problems to all organisms. Heavy metal accumulation in soils is of concern in agricultural production due to the adverse effects on food quality (safety and marketability), crop growth (due to phytotoxicity) (Ma et al., 1994; Msaky and Calvert, 1990; Fergusson, 1990) and environmental health (soil flora/fauna and terrestrial animals). The mobilization of heavy metals into the biosphere by human activity has become an important process in the geochemical cycling of these metals. This is acutely evident in urban areas where various stationary and mobile sources release large quantities of heavy metals into the atmosphere and soil, exceeding the natural emission rates (Nriagu, 1989; Bilos et al., 2001). Heavy metals in the soil can lead to toxicity symptoms and the inhibition of growth of most plants. The toxicity symptoms seen in the presence of excessive amounts of heavy metals may be due to a range of interactions at the cellular/molecular level. Toxicity may result from the binding of metals to sulphydryl groups in proteins, leading to an inhibition of activity or disruption of structure, or from the displacing of an essential element resulting in deficiency effects (Van Assche and Clijsters, 1990). In addition, heavy metal excess may stimulate the formation of free radicals and reactive oxygen species, perhaps resulting in oxidative stress (Dietz et al., 1999). Some plant species, however, have evolved tolerant races that can survive and thrive on such metalliferous soils, presumably by adapting mechanisms that may also be involved in the general homeostasis of, and constitutive tolerance to, essential metal ions as found in all plants. Plants have a range of potential mechanisms at the cellular level that might be involved in the detoxification and thus tolerance to heavy metal stress (Munne-Bosch, 2005). These all appear to be involved primarily in avoiding the build - up of toxic concentrations at sensitive sites within the cell and thus preventing the damaging effects described above, rather than developing proteins that can resist the heavy metal effects. Thus, for example, there is little evidence that tolerant species or ecotypes show an enhanced oxidative defence; rather tolerant plants show enhanced avoidance and homeostatic mechanisms to prevent the onset of stress (de Vos et al., 1991; Dietz et al., 1999). The strategies for avoiding heavy metal build- up are diverse. Tolerance could also involve the plasma membrane, either by reducing the uptake of heavy metals or by stimulating the efflux pumping of metals that have entered the cytosol. Within the protoplast a variety of potential mechanisms exist, for example, for the repair of stress- damaged proteins involving heat shock proteins or metallothioneins, and for the chelation of metals by organic acids, amino acids or peptides, or their compartmentation 
away from metabolic processes by transport into the vacuole (Dietz et al., 1999). This range of mechanisms is summarized.

The aim of the present study is using some antioxidant such as humic acid, vit C., vit E., and glutathione to improve the quality and storability of tomato and bean plants grown under soil pollution conditions and alleviation effect of residual heavy metals in fruits.

\section{MATERIALS AND METHODS}

Two field and storage experiments were conducted at private farm near the high ways at Talka City near Delta company for fertilizers and chemical industries during the two successive summer seasons of 2009 and 2010, to study the alleviation effect of humic acid, vit C., vit E., and glutathione on tomato (Lycopirsecon esculentum Mill) cv. Alissa and kidney bean (Phaseolus vulgaris L) cv. Giza 3 under soil pollution stress.

The experimental procedures:

Two experiments each included five treatments as follows:

1 - Control treatment (spray only with tap water)

2- Vitamin C (150 mg/l)

3- Vitamin $E(20 \mathrm{mg} / \mathrm{l})$

4- Humic acid $(3 \mathrm{~kg} / \mathrm{fed})$

5- Glutathione (20 mg/l)

Preceding the initiation of each experiment, soil samples to $25 \mathrm{~cm}$ depth from experimental site were collected and analyzed as shown in Table (1).

Tomato seedlings (35 day age) were transplanted in mid March in both seasons of this study at $30 \mathrm{~cm}$ apart on the side of ridge $3.5 \mathrm{~m}$ long and $1 \mathrm{~m}$ width; experimental unit area was $10.5 \mathrm{~m}^{2}$. However, kidney bean seeds were sown in mid March in hills of one plant, $20 \mathrm{~cm}$ in between two rows/ ridge of $3.5 \mathrm{~m}$ long and $60 \mathrm{~cm}$ wide; experimental unit area was $6.3 \mathrm{~m}^{2}$. A complete randomized blocks design in three replicates was adopted in both experiments.

All solutions and water were sprayed three times at 30,40 and 50 days after tomato transplanting and bean sowing except for humic acid which was added to the soil at $3 \mathrm{~kg} / \mathrm{fed}$ before planting.

\section{Experimental parameters:}

Two plants sample from each experimental unit at 60 days after tomato transplanting and bean sowing were taken. Each sample consisted of 3 plants and the following data were recorded: plant height, fresh and dry weight per plant, chlorophyll $a$ and $b$ were determined as described by Wettestein (1957). Also $\mathrm{Pb}, \mathrm{Cu}$ and $\mathrm{Mn}$ were analyzed in different plant organs (i.e., roots, leaves and fruits) according to Rangana (1979). At harvesting time after 120 days after transplanting for tomatoes and 90 days for kidney bean, fruit yield expressed as number of fruits per plant and ton per feddan were determined. At breaker stage, 10 ripe tomato fruits /plot were picked and used for determination of $\mathrm{Pb}, \mathrm{Cu}$ and $\mathrm{Mn}$ in roots, leaves and fruits. 


\section{Storage procedure:}

Tomatoes at turning stage and bean before full maturity were picked at the mid harvesting season and transported to laboratory of Mansoura Horticultural Research Station, cleaned with dry towels, graded and sorted after discarding misshaped and injured fruits and pods, where sound and healthy fruits and pods were chosen for storage experiment.

Five $\mathrm{Kg}$ for both tomato and bean fruits were put in carton box (30x 20 $x 10 \mathrm{~cm}$ ) as one replicate. The treatments were arranged in a complete randomized block design with 3 replicates. Fruits and pods for all treatments stored in cold room at $10^{\circ} \mathrm{C}, 85 \%$ R.H. and $13^{\circ} \mathrm{C}, 90 \%$ R.H., respectively for 30 days. In all stored fruits and pods, samples were taken as random from 3 replicates for each treatment and examined every day intervals to eliminate the decay fruits.

\section{Storage parameters:} days:

The following data were recorded at the end of storage period, i.e., 30

- Weight loss, and decay (in percent).

- Firmness was measured by Magness and Ballauf pressure tester with a plunger of 3/16 inch expressed as Lb/in ${ }^{2}$ and adjusted in Newton (as recommended by American Society Horticulture Science (ASHS) Post harvest Working Group).

- Acidity, ascorbic acid, lycopene and T.S.S. content were determined accorded to (A.O.A.C, 1990)

Statistical analysis:

The treatments mean were compared using the least significant differences (LSD) at $5 \%$ level of probability as described by Steel and Torrie (1980).

\section{RESULTS AND DISCUSSION}

\section{Tomato Experiment:}

\section{Vegetative growth and yield parameters:}

Data presented in Table 2 demonstrate the effect of various treatments of humic acid, vitamin $\mathrm{C}$, vitamin $\mathrm{E}$ and glutathione on vegetative growth parameters of tomato plants and fruit yield characters. All treatments were considerably differed in influencing of plant growth parameters. They were also of over growth parameters relative to the control at the two seasons.

Such data also indicated that, plants treated with glutathione and vitamin $\mathrm{C}$ were of the highest significant plant height, chlorophyll a \& b, dry weight/plant and number of fruits/plant (without significant differences between both treatments in $1^{\text {st }}$ season). While, glutathione gave the highest significant fresh weight/plant and yield ton/fed followed by vitamin C, vitamin $\mathrm{E}$ and humic acid (with no significant among them in $1^{\text {st }}$ season). In the $2^{\text {nd }}$ season, glutathione was of highest significant chlorophyll a $\& b$, fresh weight /plant and yield ton/fed followed by vitamin C. 
J. Plant Production, Mansoura Univ., Vol. 3 (1), January, 2012

$1-2$ 
On the other hand, there were no significant between both treatments in other parameters (plant height, dry weight and number of fruit /plant).

Glutathione and vitamin $C$ have each been shown to act as antioxidants in the detoxification of ROS in aerobic (Van Assche and Clijsters, 1990; Alschner, 1997). Specific roles of antioxidants may contribute to their alleviation effects recorded in the present investigation. The importance of glutathione in the process of cell of division was deduced from the notion that blocking vitamin $\mathrm{C}$ synthesis induced arrest in the cell cycle (Arrigoni et al., 1992; Citterio et al., 2005). Vitamin C could speed up the starting of the cell cycle by transferring $\mathrm{Fe}^{2+}$ more rapidly from ferritin to the enzyme deoxyribonucleotide reductase, which is responsible for DNA replication and cell cycle progression to the $\mathrm{S}$ - phase. Vitamin $\mathrm{C}$ may also indirectly enhance the progression of the cell cycle under heavy metals stress by acting as a substrate in mediated removal of toxic $\mathrm{H}_{2} \mathrm{O}_{2}$ (Arrigoni et al., 1992).

Antioxidant an important component in the plant antioxidative defense system. Vitamin $\mathrm{C}$ reduces $\mathrm{H}_{2} \mathrm{O}_{2}$ accumulation and lipid peroxidation; hence maintain membranes integrity and decreases electrolytes leakage under stress conditions (Dietz et al., 1999; Guo et al., 2005). Vitamin C, also, preventive role against heavy metals induced electrolytes leakage may maintain the osmotic potential of plant cells, hence their expansion growth (Dietz et al., 1999; Alaoui-Sossé et al., 2004)

\section{Heavy metal content:}

The effects of various natural substances of antioxidants amendments on heavy metal content $(\mathrm{Pb}, \mathrm{Mn}$ and $\mathrm{Cu})$ in the roots, leaves and fruits of tomato plants are shown in Table 3.

Data show that tomato roots accumulated higher amount of heavy metal compared with other plant organs (i.e., leaves and fruits). In characteristic most special, the concentration of $\mathrm{Pb}, \mathrm{Mn}$ and $\mathrm{Cu}$ were higher in the roots compared with those in the leaves or fruits. The control treatment led to an accumulation of the respective heavy metals content in different plant organs. Application of glutathione and vitamin $\mathrm{C}$ decreased significantly the concentration of $\mathrm{Pb}, \mathrm{Mn}$ and $\mathrm{Cu}$ in different plant organs compared to the control and other treatments in the two seasons.

This may be due to some operating mechanisms to decrease heavy metals uptake and /or to decrease their translocation from roots to leaves. It is thought that some plants possess a mechanism which limits the translocation of metals to shoots and leaves (Antosiewicz, 1992). This may be due to heavy metals fixation by functional components of cell walls, such as, polysaccharides, thio peptides (PCs) and homophytochelatins (hPCs) as mentioned by Seregin and Ivanov, 1998. Also the same authors mentioned that an accumulation of $\mathrm{Pb}$ in shoots according to them, thio peptides and homophytochelatins bind $\mathrm{Pb}$, then $\mathrm{Pb}-\mathrm{PCs}$ and $\mathrm{Pb}-\mathrm{hPCs}$ complexes are transported through the cytosol into vacuoles so, its translocation to shoots is impeded. Lower heavy metals concentration in organ of heavy metals stressed plants that treated with vitamin C may be due the likelihood that it binds metals, thereby affecting their movement across biological membranes (Gowrinathan and Rao, 1992). 
J. Plant Production, Mansoura Univ., Vol. 3 (1), January, 2012

3-4 
The corresponding affect of glutathione may be effected through altering the rates of metals uptake and elimination as wall as by chelating metal ions in cells (Rai, 1994). It has been suggested that glutathione acts as a first line of defense against metal toxicity by complexion metals before the induced synthesis of effective levels of PCs. (Yamaguchi et al., 1999; Munne-Bosch, 2005).

\section{Storage behavior and fruit chemical composition:}

Data presented in Table 4 show that the differences in means of weight loss and decay percent, firmness, total acidity, lycopene, Vit. C and T.S.S due to various application sources of natural substances of antioxidants were differed significantly in both season of study. Plants treated with tap water "control treatment" presented the highest values of fruit weight loss and decay percent, compared with other treatments in both seasons of study, while, the lowest values were recorded with glutathione and vitamin $\mathrm{E}$.

Results, also, indicated that all natural substances greatly excel significantly the control in total acidity and lycopene in $1^{\text {st }}$ season only. Meanwhile, plants treated with glutathione and vitamin $\mathrm{C}$ showed the higher significant vitamin $\mathrm{C}$ and T.S.S. in both seasons of study.

The result of the present investigation indicated that $\mathrm{Pb}, \mathrm{Mn}$ and $\mathrm{Cu}$ may be inducing oxidative stress (accumulation $\mathrm{H}_{2} \mathrm{O}_{2}$ ) in different plant organs in this concern (Smeets et al., 2005). Plant cell respond to elevated levels of oxidative stress by activating their antioxidative defense system (ROS-quenching enzymes such as catalase, peroxidase and superoxide dismutase as mentioned by Pereira et al. 2002; Smeets et al., 2005). It is well known that, the free radicals or reactive oxygen species (ROS) are very destructive to cells which cause lipid peroxidation, oxidation of protein; DNA damage; decrease membranes integrity, and cytoskeleton damage...etc. (Brussaard, et al., 2007), and thus may be weak the storability of fruits. This was complete in the control treatment (Table 4). Application of glutathione and vitamin $\mathrm{C}$ act as antioxidants in the detoxification of ROS. They have central and interrelated roles acting both chemically and as substrates in enzyme-catalyzed detoxification reactions (Pereira et al. 2002). Vitamin C is an important component of the plant antioxidant defense system and serves as a reductant for peroxidative removal of $\mathrm{H}_{2} \mathrm{O}_{2}$ (Gowrinathan and Rao, 1992). Glutathione directly reduces most ROS and maintain the ascorbate pool in plant cell (Noctor et al., 1998). The decline in titratable acidity of tomato fruit juice during storage might be attributed to the oxidation of organic acids to carbon dioxide during storage. The increase in lycopene concentration with prolongation storage period may be due to the destruction of chlorophyll and transformation of chloroplasts to chromoplasts in these material decrease firmness of fruit during storage (Hulme, 1970).

\section{Kidney bean Experiment:}

Vegetative growth and yield parameters:

Plant height, chlorophyll a \& b, dry weight per plant and number of fruits per plant and total yield of bean plants are presented in Table 5. All plants treated with natural substances of antioxidant differed in their growth parameters and were superior to the control one, in two seasons of study. Glutathione increased significantly in all studied vegetative growth characters 
followed by vitamin E compared to other treatments. Glutathione may have a direct role in cell division processes, as high concentration of this metabolite are found in rapidly - growing cell (Sanchez-Fernandez et al., 2004). Vitamin $\mathrm{E}$ antioxidants, contributes to the preservation of an adequate redox state to maintain membrane structure and function during plant responses to stress. Vitamin $\mathrm{E}$ can physically quench and therefore, deactivate singlet oxygen in membranes (Trebest et al., 2002). It has been estimated that before being degraded, one molecule of vitamin E can deactivate up to 120 singlet oxygen molecules by resonance energy transfer (Fahrenholzt et al., 1974).

\section{Heavy metal content:}

In response to heavy metals content, data in Table 6 show that, stressed kidney bean plants had the highest values of the heavy metals in various plant organs in comparison with different application of antioxidants. The roots of bean tend to accumulate higher amount of $\mathrm{Pb}, \mathrm{Cu}$, and $\mathrm{Mn}$ compared with other organs (Table 6) and lower amount of these elements than those of tomato roots (Table 3). The higher accumulation of heavy metals in bean plants compared with that in tomato plants may imply lower tolerance capacity (sensitive plants) of bean. Piechalak et al. (2002) recorded a significant increase in $\mathrm{Pb}$ content in leaves of Phaseolus vulgaris subjected to $\mathrm{Pb}$ stress. In two seasons, application of antioxidants to bean plants had a significant decrease in all heavy metals content in different plant organs.

Vitamin E can chemically scavenge lipid peroxyl radicals (MunneBosch, 2005). Vit. E able to protect cellular structures against oxidative degradation processes (Schmitz-Eiberger and Noga, 2001).

Application of humic acid enhanced most parameters, but it gave the lowest values compared to other treatments and superior to the control. In general, Humic acid has a number of potential benefits for plants: increased water and nutrient holding capacity; increased reserve of slow release nutrients; enhanced solubility of phosphorus, zinc, iron, manganese, and copper; increased resistance to soil $\mathrm{pH}$ change; improved soil aggregation; enlarged root system and increased stimulation of plant-growth due to hormones (Stevenson, 1994; Bryan and Stark, 2003; Mikkelsen, 2005).

Storage behavior and fruit chemical composition:

Data in Table 7 indicate that application of antioxidant were of significant higher values of firmness, total acidity, Vit. C and T.S.S and lower significant values of weight loss and decay percent than those of the control one in both seasons. Glutathione and Vit. E were the best treatments, in this respect. Moreover, vitamin $\mathrm{E}$ prevents the propagation of lipid peroxidation by scavenging ROS (Munne-Bosch, 2005). The result in the same table indicate a progressive increase in the percentage of loss in bean weight during storage .These might be due to the loss in moisture through transpiration and loss in dry matter content through respiration process (El-Sheikh and Salama, 1997). It is clear from the same data that the decay percentage of fruit increased considerably and consistently with the prolongation of storage. These results may be due to the continous chemical and biochemical change happened in the fruit such as moisture condensation and transformation of complex compounds to simple. 
Shabana, Abeer A. et al.

5-6 
J. Plant Production, Mansoura Univ., Vol. 3 (1), January, 2012

7 
It could be concluded that, application of glutathione, vitamin $C$ and vitamin $\mathrm{E}$ as a natural substances of antioxidants to tomato and kidney bean plants indicated that the most effective treatments for improvement quality and storability and alleviate the adverse effects of some heavy metals under soil pollution conditions.

\section{REFERENCES}

Alaoui-Sossé, B.; P. Genet; F. Vinit-Dunand; M. Toussaint; D. Epron, and P. Badot. 2004. Effect of copper on growth in cucumber plants (Cucumis sativus) and its relations with carbohydrate accumulation and changes in ion contents. Plant Sci., 166: 1213-1218.

Alloway, B. J. 1995. Trace elements in soil and plant. $2^{\text {nd }}$ Ed. CRC Press, Boca Raton, SLA.

Alschner, R. G.; J. L. Donahue, and C. L. Cramer. 1997. Reaction oxygen species and antioxidants: Relationships in green cells. Physiol. Plant., 100: 224-223.

Antosiewicz, D. M. 1992. Adaptation of plants to an environment polluted with heavy metals. Act. Soc. Bot. Pol., 61: 281-299.

AOAC (Association of Official Analytical Chemists). 1990. Official Methods of Analysis. $15^{\text {th }}$ Ed., Washington, DC, USA.

Arrigoni, O.; L. DeGara; F. Tommasi, and R. Liso. 1992. Changes in the ascorbate system during seed development of Vicia faba L. Plant Physiol., 99: 235-238.

Bilos, C.; J. C. Colombo; C. N. Skorupka, and M. J. Rodriguez Presa. 2001. Source, distribution and variability of airborne trace metals in La Plata City area, Argentina. Environ Pollut., 111(1):149-158.

Brussaard, L.; P. C. de Ruiter, and G. G. Brown. 2007. "Soil biodiversity for agricultural sustainability”. Agric., Ecosys. Environ., 121: 233-244.

Bryan, H. and J. Stark. 2003. Humic acid effects on potato response to phosphorus. Idaho Potato Conference, USA, January 22-23, pp 5.

Citterio, S.; H. Prato; P. Fumagalli; R. Aina; N. Massa; A. Santagostino; S. Sgorbatis and G. Berta. 2005. The arbuscular mycorrhizal fungus Glomus mosseae induces growth and metal accumulation change sin Cannabis sativa L. Chemosphere, 59: 21-29.

De Vos, C. H. R.; H. Schat; M. A. M. De Waal; R. Vooijs, and W. H. O. Ernst. 1991. Increased resistance to copper induced damage of the root cell plasmalemma in copper tolerant Silene cucubalus. Physiol. Plant., 82: 523-528.

Dietz, K. J.; M. Baier, and U. Krämer. 1999. Free radicals and reactive oxygen species as mediators of heavy metal toxicity in plants. In: Prasad MNV, Hagemeyer J., eds. Heavy metal stress in plants: from molecules to ecosystems. Berlin: Springer-Verlag, pp. 73-97.

El-Sheikh, T. M. and G. M. Salama. 1997. Influence of chicken manure on growth, yield, fruit quality and storability of tomatoes. Annals of Agric. Sci., Moshtohor, 35 (4): 2391-2413. 
Fahrenholzt, S. R.; F. H. Doleiden; A. M. Tozzolo, and A. A. Lamola. 1974. On the quenching of singlet oxygen by $\dot{\alpha}^{-}$tocopherol. Photochem. Photobiol., 20: 505-509.

Fergusson, J. E. 1990. The Heavy Elements: Chemistry, Environmental Impact and Health Effects. Oxford: Pergamin Press, pp. 382-399.

Gowrinathan, K. P. and V. N. R. Rao. 1992. Reversed of heavy metal toxicity by ascorbic acid in microalgae. J. Swa. Bot., 9: 27-29.

Guo, Z.; H. Tan; Z. Zhu; S. Lu, and B. Zhou. 2005. Effect of intermediates on ascorbic acid and oxalate biosynthesis of rice and in relation to its stress resistance. Plant Physiol. Biochem., 43: 955-962.

Ma, Q. Y.; S. J. Traina, and T. J. Logan. 1994. Effect of aqueous Al, Cd, $\mathrm{Fe}(\mathrm{II}), \mathrm{Ni}$ and $\mathrm{Zn}$ on $\mathrm{Pb}$ immobilization by hydroxyapatite. Environ. Sci. Technol.; 28 (7):1219-1228.

Hulme, A. C. 1970. The Biochemistry of Fruits and their Products. Academic Press, London and New York.

Mikkelsen, R.L. 2005. Humic materials for agriculture. Better Crops, 89 (3): 610.

Msaky J. J. and R. Calvert. 1990. Adsorption behavior of copper and zinc in soils: Influence of $\mathrm{pH}$ on adsorption characteristics. Soil Sci., 150 (2): 513-522.

Munne-Bosch, S. 2005. The role of $\dot{\alpha}$-tocopherol in plant stress tolerance. J. Plant Physiol., 162: 743-748.

Noctor, G.; A. C. M. Arisi; L. Jouanin; K. J. Kunert; H. Rennenberg, and C. H. Foyer. 1998. Glutathione: Biosynthesis, metabolism and relationship to stress tolerance explored in transformed plants. J. Exp. Bot., 49: 623647.

Nriagu J. O. 1989. A global assessment of natural sources of atmospheric trace metals. Nature, 338 (6210): 47-49.

Piechalak A.; B. Tomaszewska; D. Baralkiewicz, and A. Malecka. 2002. Accumulation and detoxification of lead ions in legumes. Phytochem., 60: 153-162.

Rai, L. C. 1994. Mercuric chloride effect on chlorella 1-Reversal of toxicity by ascorbic acid and reduced glutathione. Pykos., 18:105-109.

Rangana, S. 1979. Manual Analysis of Fruit and Vegetable Products. Tata McGraw Hill Pub. Co. Ltd. New Delhi, pp 363.

Sanchez-Blanco, M. J.; T. Fernandez; M. A. Morales; A. Morte, and J. J. Alarcon. 2004. Variations in water status, gas exchange, and growth in Rosmarinus officinalis plant infected with Glomus deserticola under drought conditions. Plant Physiol., 161: 675-682.

Schmitz-Eiberger, M. and G. Noga. 2001. Reduction of paraquat -induced oxidative stress in Phaseolus vulgaris and Malus domestica leaves by $\dot{\alpha}$ -tocopherol. Sci. Hort., 91:153-167.

Seregin, I. V. and V. B. Ivanov. 1998. The transport of cadmium and lead toxic effects on higher plants. Russ. J. Plant Physiol., 48: 523-544.

Smeets, K.; A. Cuypers; A. Lambrechts; B. Semane; P, Hoet; A. Van Laere, and J. Vangronsveld. 2005. Induction of oxidative stress and antioxidative mechanisms in Phaseolus vulgaris after $\mathrm{Cd}$ application. Plant Physiol. Biochem., 43: 437-444. 


\section{Shabana, Abeer A. et al.}

Steel, R. G. D. and J. H. Torrie. 1980. Principles and Procedures of Statistics. A Biometrical Approach. $2^{\text {nd }}$ Ed. McGraw-Hill Publishing Co., New York, USA.

Stevenson, F. J. 1994. Humus Chemistry: Genesis, Composition, Reaction. $2^{\text {nd }}$ Ed. John Wiley and Sons, Inc., New York.

Trebest, A.; B. Depka, and H. Hollander-Czytko. 2002. A specific role for tocopherol and of chemical singlet oxygen quenchers in the maintenance of photosystem 11 structure and function in Chalmydomonas reinhardtii. FEBS Letters, 516: 156-160.

Van Assche F. and H. Clijsters. 1990. Effects of metals on enzyme activity in plants. Plant, Cell and Environment, 13:195-206.

Wettestein, D. 1957. Chlorophyll Lethale un der Submikroskopische Formwechsel der Plastiden. Exptl. Cell Reso., 12: 427-506.

Yamaguchi, Y.; Y. Yamamoto; H. Ikegawa, and H. Matsumoto. 1999. Protective effect of glutathione on the cytoxicity caused by a combination of aluminum and iron in suspension- cultured tobacco cells. Physiol. Plant., 105: 417-422.

تخفيف الأثر الضــار لبعض العناصـر الثقيلـة وتحسين الجـودة والقابليـة التخزنيـة

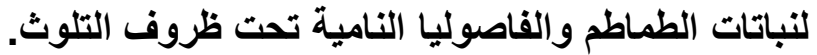

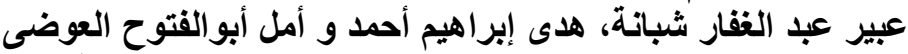

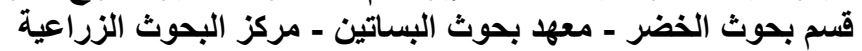

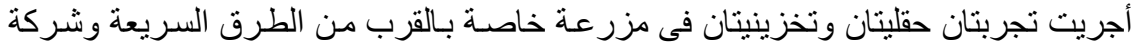

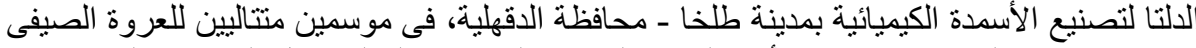

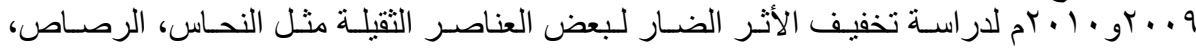

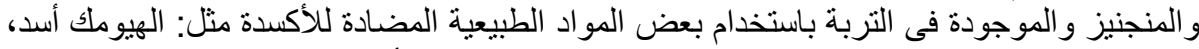

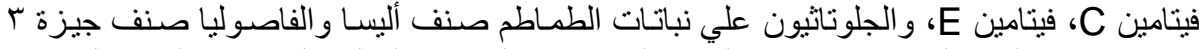

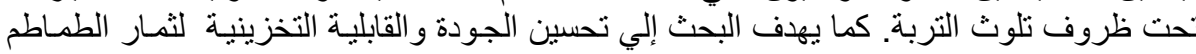

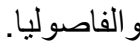
وكانت أهم النتائج المتحصل عليها كما يلي:

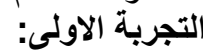

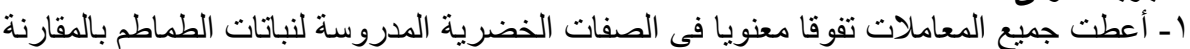

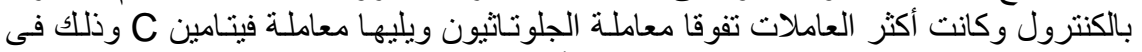

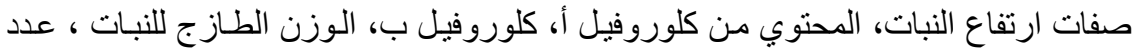

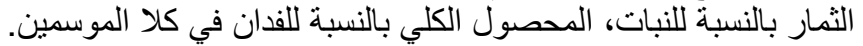

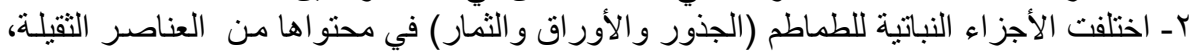

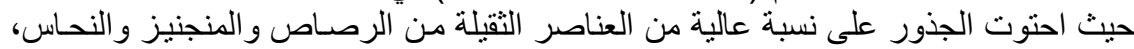

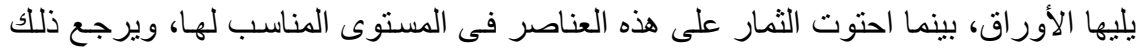

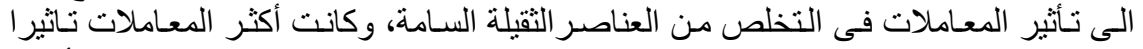

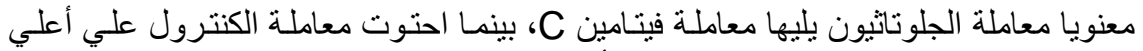
نسبة من العناصر الثقبلة سواء في الجذر ، الأور اق ،و الثمار فى كلا الموسمين. 


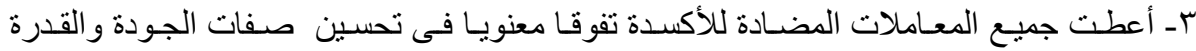

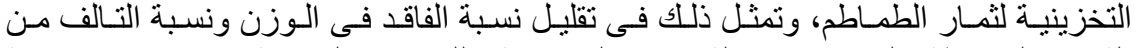

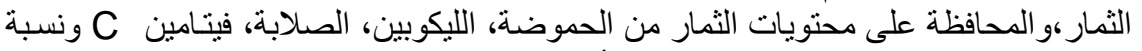

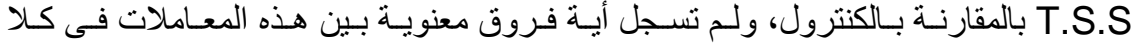

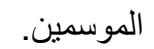

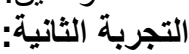

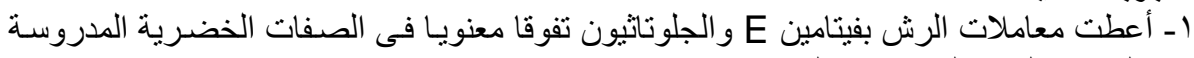
لنباتات الفاصوليا في كلا الموسمين.

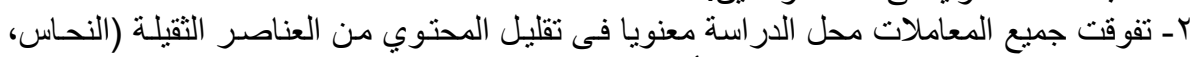

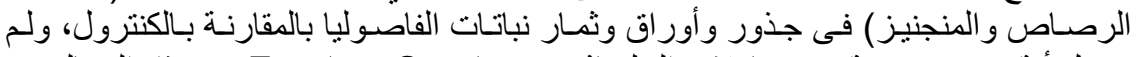

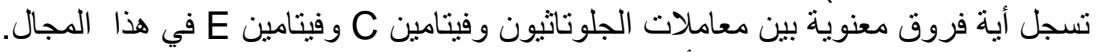

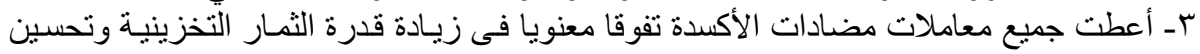

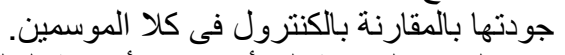

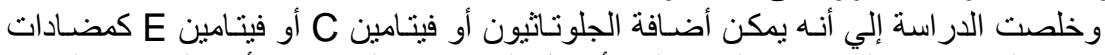

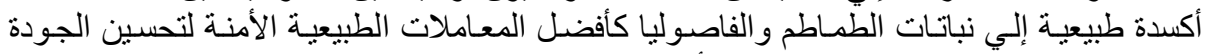

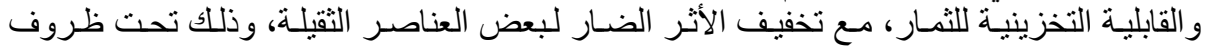

كلية الزراعة - جامعة المنصورة

قام بتحكيم البحث المركز القومي للبحوث

\author{
أ.د / كوثر كامل ضون الجه
}

أ.د / السيد محمود سنجر 
Shabana, Abeer A. et al. 


\section{J. Plant Production, Mansoura Univ., Vol. 3 (1): 1 - 15, 2012}

Table 1: Some physical and chemical properties of the experimental soil in 2009 and 2010 seasons.

\begin{tabular}{|c|c|c|c|c|c|c|}
\hline \multirow{2}{*}{$\begin{array}{c}\text { Some Physical } \\
\text { properties }\end{array}$} & \multicolumn{2}{|c|}{ Values } & \multirow{2}{*}{\multicolumn{2}{|c|}{$\begin{array}{c}\text { Some Chemical } \\
\text { Properties }\end{array}$}} & \multicolumn{2}{|c|}{ Values } \\
\hline & 2009 & 2010 & & & $1^{\text {st }}$ season & $2^{\text {nd }}$ season \\
\hline Coarse sand (\%) & 1.97 & 1.52 & \multirow{8}{*}{$\begin{array}{l}\text { meq / } 100 \mathrm{~g} \\
\text { soil }\end{array}$} & $\mathrm{Ca}^{++}$ & 1.92 & 2.00 \\
\hline Fine sand & 17.81 & 17.96 & & $\mathrm{Mg}^{++}$ & 3.80 & 3.65 \\
\hline Silt (\%) & 29.13 & 29.69 & & $\mathrm{Na}^{++}$ & 2.43 & 2.41 \\
\hline Clay (\%) & 51.09 & 50.83 & & $\mathrm{~K}^{+}$ & 0.99 & 1.05 \\
\hline Texture class & Clayey & Clayey & & $\mathrm{CO}_{3}^{--}$ & 0.00 & 0.00 \\
\hline $\mathrm{CaCO}_{3}(\%)$ & 2.81 & 2.60 & & $\mathrm{HCO}_{3}{ }^{-}$ & 1.76 & 1.69 \\
\hline Organic matter (\%) & 2.03 & 1.80 & & $\mathrm{Cl}^{-}$ & 1.96 & 2.03 \\
\hline $\mathrm{pH}$ value & 8.1 & 7.9 & & $\mathrm{SO}_{4}^{--}$ & 1.55 & 1.48 \\
\hline $\mathrm{EC} \mathrm{dSm}^{-1}$ & 1.03 & 1.12 & \multicolumn{2}{|c|}{ Heavy metals } & -- & -- \\
\hline Available N (ppm) & 47.50 & 45.58 & \multirow{3}{*}{$\begin{array}{l}\text { Available } \\
\text { (ppm) }\end{array}$} & $\mathrm{Pb}$ & 485 & 418 \\
\hline Available P (ppm) & 12.3 & 12.1 & & $\mathrm{Cu}$ & 69 & 78 \\
\hline Available K (ppm) & 304 & 295 & & $\mathrm{Mn}$ & 1852 & 1963 \\
\hline
\end{tabular}

Critical levels: Pb 100 and 30; Mn 1500 and 300; Cu 60 and 20 ppm, in soil and plant, respectively according to Alloway, 1995.

Table 2: Vegetative growth characters and yield parameters of tomato plants as affected by natural substances of antioxidants in 2009 and 2010 seasons.

\begin{tabular}{|c|c|c|c|c|c|c|c|}
\hline \multirow[b]{2}{*}{$\begin{array}{l}\text { Characters } \\
\text { Treatments }\end{array}$} & \multicolumn{7}{|c|}{ Season 2009} \\
\hline & $\begin{array}{l}\text { Plant height } \\
\quad \text { (cm) }\end{array}$ & $\begin{array}{c}\text { Chlorophyll A } \\
\text { (mg/g F.W.) }\end{array}$ & $\begin{array}{c}\text { Chlorophyll B } \\
\text { (mg/g F.W.) }\end{array}$ & $\begin{array}{c}\text { Fresh } \\
\text { weight/plant } \\
(\mathrm{g})\end{array}$ & $\begin{array}{c}\text { Dry weight/plant } \\
\text { (g) }\end{array}$ & Fruit No./plant & $\begin{array}{c}\text { Yield } \\
\text { (ton/fed) }\end{array}$ \\
\hline $\begin{array}{l}\begin{array}{l}\text { 1. Control (distillated } \\
\text { water) }\end{array} \\
\end{array}$ & 53.33 & 2.76 & 1.27 & 488.00 & 53.16 & 20.33 & $8.99 \mathrm{c}$ \\
\hline 2. Humic acid & 59.33 & 4.54 & 2.62 & 542.33 & 70.20 & 29.66 & 12.89 \\
\hline 3. Vitamin C & 72.0 & 4.91 & 2.73 & 1094.33 & 154.93 & 38.00 & 13.59 \\
\hline 4. Vitamin $\mathrm{E}$ & 72.33 & 3.6 & 2.73 & 922.03 & 123.86 & 31.00 & 11.95 \\
\hline 5. Glutathione & 76.33 & 4.91 & 2.73 & 1400.40 & 166.36 & 38.00 & 15.22 \\
\hline LSD at $5 \%$ & 5.56 & 0.19 & 0.05 & 205.98 & 20.19 & 3.91 & 2.16 \\
\hline Treatments & \multicolumn{7}{|c|}{ Season 2010} \\
\hline $\begin{array}{l}\text { 1. Control (distillated } \\
\text { water) }\end{array}$ & 43.67 & 2.63 & 1.22 & 495.00 & 53.83 & $21.33 c$ & 8.87 \\
\hline 2. Humic acid & 58.33 & 4.43 & 2.48 & 552.33 & 72.53 & $30.67 \mathrm{~b}$ & 13.02 \\
\hline 3. Vitamin $C$ & 71.33 & 4.65 & 2.48 & 1081.00 & 156.93 & $37.67 \mathrm{a}$ & 13.74 \\
\hline 4. Vitamin $\mathrm{E}$ & 71.00 & 3.49 & 2.44 & 912.03 & 127.20 & $31.33 \mathrm{~b}$ & 11.80 \\
\hline 5. Glutathione & 74.33 & 4.79 & 2.62 & 1389.77 & 179.70 & $36.67 \mathrm{a}$ & 15.86 \\
\hline LSD at $5 \%$ & 5.16 & 0.231 & 0.051 & 208.51 & 24.34 & 4.29 & 1.12 \\
\hline
\end{tabular}


Shabana, Abeer A. et al.

Table 3: Heavy metal content of tomato plants as affected by natural substances of antioxidants in 2009 and 2010 seasons.

\begin{tabular}{|c|c|c|c|c|c|c|c|c|c|}
\hline \multirow{3}{*}{$\begin{array}{l}\text { Characters } \\
\text { Treatments }\end{array}$} & \multicolumn{9}{|c|}{ Season 2009} \\
\hline & \multicolumn{3}{|c|}{$\mathrm{Pb}(\mathrm{mg} / \mathrm{kg})$} & \multicolumn{3}{|c|}{ Mn (mg/kg) } & \multicolumn{3}{|c|}{$\mathrm{Cu}(\mathrm{mg} / \mathrm{kg})$} \\
\hline & Roots & Leaves & Fruits & Roots & Leaves & Fruits & Roots & Leaves & Fruits \\
\hline \begin{tabular}{|ll} 
(distillated water) & Control \\
(d)
\end{tabular} & 658.62 & 320.14 & 200.56 & 6368.74 & 4161.11 & 3177.67 & 554.37 & 214.13 & 200.65 \\
\hline 2. Humic acid & 160.01 & 22.46 & 17.43 & 905.013 & 313.78 & 24.72 & 212.12 & 21.48 & 14.70 \\
\hline 3. Vitamin C & 145.17 & 21.77 & 10.27 & 505.58 & 219.81 & 22.38 & 287.75 & 24.49 & 10.65 \\
\hline 4. Vitamin $\mathrm{E}$ & 235.61 & 22.06 & 14.16 & 690.92 & 333.68 & 34.2 & 353.64 & 31.72 & 15.71 \\
\hline 5. Glutathione & 323.46 & 31.71 & 10.27 & 489.93 & 222.23 & 32.10 & 231.93 & 23.95 & 10.27 \\
\hline LSD at $5 \%$ & 24.06 & 8.02 & 1.11 & 103.17 & 92.02 & 26.03 & 16.70 & 5.20 & 0.57 \\
\hline Treatments & \multicolumn{9}{|c|}{ Season 2010} \\
\hline $\begin{array}{|ll|}1 . & \text { Control } \\
\text { (distillated water) }\end{array}$ & 751.96 & 315.81 & 204.89 & 6178.73 & 4217.78 & 4064.33 & 621.37 & 204.80 & 208.98 \\
\hline 2. Humic acid & 173.35 & 21.80 & 17.10 & 860.01 & 320.12 & 21.72 & 247.46 & 21.48 & 14.37 \\
\hline 3. Vitamin C & 155.17 & 22.10 & 11.60 & 533.91 & 233.14 & 22.72 & 278.09 & 25.83 & 11.32 \\
\hline 4. Vitamin E & 248.94 & 21.73 & 14.49 & 684.25 & 320.68 & 34.86 & 343.98 & 31.72 & 16.37 \\
\hline 5. Glutathione & 296.80 & 31.05 & 11.45 & 466.59 & 229.60 & 32.76 & 210.93 & 24.95 & 11.27 \\
\hline LSD at $5 \%$ & 26.98 & 5.25 & 3.31 & 74.93 & 54.89 & 560.94 & 58.86 & 1.48 & 7.18 \\
\hline
\end{tabular}

Table 4: Storage behavior characters and chemical constituents of tomato fruits as affected by natural substances in 2009 and 2010 seasons.

\begin{tabular}{|c|c|c|c|c|c|c|c|}
\hline \multirow{2}{*}{\begin{tabular}{|l|}
\multicolumn{1}{|c|}{ Characters } \\
Treatments \\
\end{tabular}} & \multicolumn{7}{|c|}{ Season 2009} \\
\hline & $\begin{array}{c}\text { Weight loss } \\
(\%)\end{array}$ & $\begin{array}{c}\text { Decay } \\
(\%)\end{array}$ & \begin{tabular}{|c|} 
Total acidity \\
(mg/100gm F.W.) \\
\end{tabular} & $\begin{array}{c}\text { Lycopene } \\
\text { (mg/100gm F.W.) }\end{array}$ & firmness & \begin{tabular}{|c|} 
Vit. C \\
(mg/100gm F.W.) \\
\end{tabular} & $\begin{array}{l}\text { T.S.S. } \\
(\%)\end{array}$ \\
\hline $\begin{array}{l}1 . \quad \text { Control (distillated } \\
\text { water) }\end{array}$ & 48.33 & 99.00 & 0.226 & 0.333 & 33.69 & 16.97 & 4.00 \\
\hline 2. Humic acid & 3.20 & 5.50 & 0.346 & 0.466 & 46.93 & 25.72 & 5.00 \\
\hline 3. Vitamin $C$ & 3.33 & 3.20 & 0.360 & 0.560 & 53.46 & 31.74 & 5.67 \\
\hline 4. Vitamin $\mathrm{E}$ & 2.80 & 0.00 & 0.340 & 0.540 & 50.30 & 27.66 & 4.33 \\
\hline 5. Glutathione & 2.23 & 0.00 & 0.310 & 0.580 & 53.46 & 32.67 & 6.00 \\
\hline LSD at $5 \%$ & 1.26 & 0.84 & 0.205 & 0.206 & 0.09 & 3.43 & 0.77 \\
\hline Treatments & \multicolumn{7}{|c|}{ Season 2010} \\
\hline $\begin{array}{l}\begin{array}{l}\text { 1. Control (distillated } \\
\text { water) }\end{array} \\
\end{array}$ & 47.67 & 99.33 & 0.486 & 0.339 & 33.36 & 17.30 & 4.33 \\
\hline 2. Humic acid & 3.17 & 5.45 & 0.350 & 0.477 & 46.93 & 27.05 & 5.33 \\
\hline 3. Vitamin C & 3.45 & 3.26 & 0.371 & 0.561 & 51.79 & 32.41 & 6.00 \\
\hline 4. Vitamin $\mathrm{E}$ & 2.85 & 0.00 & 0.340 & 0.560 & 51.96 & 28.66 & 5.00 \\
\hline 5. Glutathione & 2.30 & 0.00 & 0.342 & 0.578 & 52.88 & 34.33 & 5.67 \\
\hline LSD at $5 \%$ & 1.23 & 0.96 & 0.023 & 0.210 & 1.36 & 3.98 & 0.91 \\
\hline
\end{tabular}


Table 5: Vegetative growth characters and yield parameters of kidney bean plants as affected by natural substances of antioxidants in $2007 / 08$ and $2008 / 09$ seasons.

\begin{tabular}{|c|c|c|c|c|c|c|c|}
\hline \multirow{2}{*}{\begin{tabular}{|l} 
Characters \\
Treatments
\end{tabular}} & \multicolumn{7}{|c|}{ Season $2007 / 08$} \\
\hline & $\begin{array}{l}\text { Plant height } \\
\text { (cm) }\end{array}$ & $\begin{array}{c}\text { Chlorophyll A } \\
\text { (mg/g F.W.) }\end{array}$ & $\begin{array}{c}\text { Chlorophyll B } \\
\text { (mg/g F.W.) }\end{array}$ & $\begin{array}{c}\text { Fresh } \\
\text { weight/plant } \\
\text { (g) }\end{array}$ & $\begin{array}{l}\text { Dry weight/plant } \\
\text { (g) }\end{array}$ & Fruit No./plant & Yield ton /Fed \\
\hline $\begin{array}{l}\text { 1. Control (distillated } \\
\text { water) }\end{array}$ & 47.00 & 2.50 & 1.33 & 85.33 & 22.56 & 29.33 & 1.84 \\
\hline 2. Humic acid & 47.66 & 2.95 & 1.63 & 128.00 & 32.00 & 41.67 & 2.22 \\
\hline 3. Vitamin C & 51.33 & 3.54 & 1.74 & 111.00 & 31.97 & 40.67 & 2.62 \\
\hline 4. Vitamin $\mathrm{E}$ & 53.33 & 4.65 & 2.95 & 160.00 & 37.23 & 41.67 & 2.90 \\
\hline 5. Glutathione & 54.66 & 5.42 & 3.29 & 172.00 & 41.93 & 44.67 & 3.15 \\
\hline LSD at $5 \%$ & 3.20 & 0.08 & 0.07 & 29.37 & 9.05 & 13.32 & 0.22 \\
\hline Treatments & & & & eason $2008 / 09$ & & & \\
\hline 1.Control (distillated water) & 46.66 & 2.70 & 1.60 & 87.33 & 23.58 & 33.66 & 1.75 \\
\hline 2. Humic acid & 53.33 & 2.96 & 1.73 & 131.33 & 32.66 & 43.66 & 2.88 \\
\hline 3. Vitamin C & 49.33 & 5.75 & 1.86 & 112.67 & 35.30 & 45.00 & 2.65 \\
\hline 4. Vitamin E & 54.66 & 3.87 & 3.04 & 163.67 & 37.90 & 43.33 & 2.98 \\
\hline 5. Glutathione & 55.00 & 5.31 & 3.46 & 178.00 & 42.89 & 46.66 & 3.88 \\
\hline LSD at $5 \%$ & 2.65 & 0.78 & 0.35 & 23.69 & 6.79 & 5.81 & 0.25 \\
\hline
\end{tabular}

Table 6: Heavy metal content of kidney bean plants as affected by natural substances of antioxidants in $2007 / 08$ and 2008/09 seasons.

\begin{tabular}{|c|c|c|c|c|c|c|c|c|c|}
\hline \multirow{3}{*}{\begin{tabular}{|l|}
\multicolumn{1}{|c|}{ Characters } \\
Treatments
\end{tabular}} & \multicolumn{9}{|c|}{ Season $2007 / 08$} \\
\hline & \multicolumn{3}{|c|}{$\mathrm{Pb}(\mathrm{mg} / \mathrm{kg})$} & \multicolumn{3}{|c|}{ Mn (mg/kg) } & \multicolumn{3}{|c|}{$\mathrm{Cu}(\mathrm{mg} / \mathrm{kg})$} \\
\hline & Roots & Leaves & Fruits & Roots & Leaves & Fruits & Roots & Leaves & Fruits \\
\hline $\begin{array}{lll}1 . & \text { Control (distillated } \\
\text { water) }\end{array}$ & 567.13 & 324.59 & 330.27 & 5216.85 & 3193.80 & 3093.26 & 416.94 & 200.32 & 200.16 \\
\hline 2. Humic acid & 153.71 & 41.49 & 11.54 & 3250.58 & 216.93 & 22.67 & 315.40 & 55.43 & 13.12 \\
\hline 3. Vitamin C & 152.80 & 41.85 & 10.21 & 2634.17 & 198.35 & 10.41 & 191.84 & 40.60 & 10.53 \\
\hline 4. Vitamin $\mathrm{E}$ & 142.66 & 44.47 & 10.52 & 2389.34 & 214.94 & 11.48 & 181.91 & 43.98 & 10.35 \\
\hline 5. Glutathione & 122.66 & 41.99 & 10.21 & 1465.71 & 104.98 & 9.86 & 194.33 & 30.49 & 10.29 \\
\hline LSD at $5 \%$ & 50.37 & 9.17 & 8.96 & 135.32 & 1317.01 & 50.935 & 5.75 & 4.96 & 0.136 \\
\hline Treatments & & & & & Season 20 & & & & \\
\hline $\begin{array}{l}\text { 1. Control (distillated } \\
\text { water) }\end{array}$ & 500.46 & 305.25 & 277.17 & 5100.85 & 4104.13 & 2977.60 & 300.27 & 200.31 & 190.21 \\
\hline 2. Humic acid & 100.38 & 39.49 & 9.626 & 3280.25 & 220.93 & 22.67 & 200.40 & 55.43 & 12.79 \\
\hline 3. Vitamin C & 109.47 & 42.52 & 10.21 & 2596.17 & 233.68 & 10.32 & 195.84 & 40.61 & 13.27 \\
\hline 4. Vitamin $\mathrm{E}$ & 132.66 & 40.72 & 10.17 & 2498.67 & 182.94 & 11.48 & 186.57 & 43.98 & 12.30 \\
\hline 5. Glutathione & 124.00 & 38.11 & 8.27 & 1624.54 & 97.98 & 9.45 & 191.33 & 30.50 & 11.41 \\
\hline LSD at $5 \%$ & 10.30 & 5.72 & 12.99 & 297.50 & 84.64 & 132.47 & 10.89 & 4.96 & 8.34 \\
\hline
\end{tabular}


Shabana, Abeer A. et al.

Table 7: Storage behavior characters and chemical constituents of kidney bean plants as affected by natural substances of antioxidants in 2007/08 and 2008/09 seasons.

\begin{tabular}{|c|c|c|c|c|c|c|}
\hline \multirow{2}{*}{\begin{tabular}{|l|}
\multicolumn{1}{|c|}{ Characters } \\
Treatments
\end{tabular}} & \multicolumn{6}{|c|}{ Season $2007 / 08$} \\
\hline & $\begin{array}{c}\text { Weight loss } \\
(\%)\end{array}$ & $\begin{array}{c}\text { Decay } \\
(\%)\end{array}$ & $\begin{array}{c}\text { Total acidity } \\
\text { (mg/100gm F.W.) }\end{array}$ & firmness & $\begin{array}{c}\text { Vit. C } \\
\text { (mg/100gm F.W.) }\end{array}$ & $\begin{array}{c}\text { T.S.S. } \\
(\%)\end{array}$ \\
\hline $\begin{array}{l}\text { 1. Control (distillated } \\
\text { water) }\end{array}$ & 53.66 & 70.00 & 0.627 & 33.02 & 11.67 & 4.33 \\
\hline 2. Humic acid & 5.33 & 6.00 & 0.490 & 47.93 & 14.00 & 6.66 \\
\hline 3. Vitamin C & 2.00 & 4.67 & 0.346 & 51.66 & 15.00 & 6.66 \\
\hline 4. Vitamin $\mathrm{E}$ & 1.33 & 2.33 & 0.333 & 56.00 & 16.00 & 7.00 \\
\hline 5. Glutathione & 1.17 & 1.00 & 0.300 & 56.67 & 18.00 & 7.00 \\
\hline LSD at $5 \%$ & 3.09 & 8.46 & 0.058 & 2.20 & 1.94 & 0.91 \\
\hline \begin{tabular}{|l|} 
Treatments \\
\end{tabular} & \multicolumn{6}{|c|}{ Season 2008/09 } \\
\hline $\begin{array}{ll}\begin{array}{l}1 . \\
\text { water) }\end{array} & \text { Control (distillated } \\
\end{array}$ & 57.16 & 73.33 & 0.66 & 30.64 & 11.16 & 4.16 \\
\hline 2. Humic acid & 5.66 & 6.33 & 0.56 & 48.36 & 14.00 & 5.33 \\
\hline 3. Vitamin C & 2.33 & 5.10 & 0.39 & 51.33 & 14.66 & 6.67 \\
\hline 4. Vitamin E & 1.66 & 2.83 & 0.34 & 55.66 & 15.66 & 6.50 \\
\hline 5. Glutathione & 1.17 & 1.33 & 0.36 & 58.23 & 18.66 & 7.33 \\
\hline LSD at $5 \%$ & 2.70 & 4.95 & 0.06 & 4.24 & 1.29 & 1.02 \\
\hline
\end{tabular}

